\title{
Découpage du savoir, apprentissage et transfert de connaissance
}

Fabienne Tanon

\section{(2) OpenEdition}

12 Journals

Édition électronique

URL : https://journals.openedition.org/tc/461

DOI : $10.4000 /$ tc. 461

ISSN : 1952-420X

Éditeur

Éditions de l'EHESS

\section{Édition imprimée}

Date de publication : 1 novembre 1997

ISSN : 0248-6016

\section{Référence électronique}

Fabienne Tanon, « Découpage du savoir, apprentissage et transfert de connaissance », Techniques \& Culture [En ligne], 28 | 1997, mis en ligne le 28 octobre 2005, consulté le 29 septembre 2022. URL :

http://journals.openedition.org/tc/461 ; DOI : https://doi.org/10.4000/tc.461

Ce document a été généré automatiquement le 29 septembre 2022.

Tous droits réservés 


\section{Découpage du savoir, apprentissage et transfert de connaissance}

Fabienne Tanon 